\title{
Uji Potensi Ekstrak Kasar Teripang Laut Holothuria atra Untuk Anti Kanker Dengan Menggunakan Metode Brine Shirmp Lethality Test
}

\author{
(The Potential Test of Sea Cucumber Crude Extract Holothuria atra for anti-cancer \\ Using Brine Shirmp Lethality Test Method)
}

Yunita Baramuli ${ }^{1}$, Nickson J. Kawung ${ }^{2}$, Fitje Losung ${ }^{2}$, James J.H. Paulus ${ }^{2}$ Inneke F.M. Rumengan ${ }^{2}$, Billy Th. Wagey ${ }^{2}$, Fransin Manginsela ${ }^{3}$.

1. Mahasiswa Program Studi IImu Kelautan, FPIK, UNSRAT Manado

2. Staf Pengajar Program Studi IImu Kelautan, FPIK, UNSRAT Manado

3. Staf Pengajar Program Studi Manajemen Sumberdaya Perairan, FPIK UNSRAT Manado

Penulis korespondensi: Nickson Kawung; Kawungnickson@yahoo.com

\begin{abstract}
The aim of this research is to test the potency of Sea cucumber crude extract Holothuria atra using the shrimp larvae Artemia salina Leach. The sample were take from waters of tateli at Minahasa District. Sample preparation and the potential test were done at biology moleculer and marien pharmacy laboratorium of Faculty of Fhiseries and Marine Science Sam Ratulangi University. The sample macerated once with ethanol for 24 hours. Extract of the sample were conentrated using rotary evaporator. Using the Brine Shrimp Lethality Test (BSLT) method with shrimp larvae Artemia salina, Leach. As the sample dry weight of the sample is $420 \mathrm{~g}$ after macerated with ethanol then decreased to $18 \mathrm{~g}$ after evaporated. Probit analysis of larva mortalityt data as the indicator of anticancer potential shown the value LC $5030.01 \mathrm{mg} / \mathrm{l}$. Bioactive compounds of sea cucumber $\mathrm{H}$. arta has potency to be develop as anti-cancer material.
\end{abstract}

Keywords: Potential Test, Anticancer, Sea Cucumber, Holothuria atra, Artemia salina leach.

\begin{abstract}
ABSTRAK
Uji potensi antikanker dari ekstrak kasar teripang Holoturia atra dengan menggunakan larva udang Artemia salina Leach adalah tujuan dari penelitian ini. Sampel diambil diperairan Tateli kabupaten Minahasa. Kemudian preparasi sampel dan uji potensi dilakukan di Laboratorium Biologi molekuler dan Farmasitika Laut Fakultas Perikanan dan Ilmu Kelautan Universitas Sam Ratulangi. Sampel dimaserasi dengan etanol selama $1 \times 24$ jam. Ekstrak sampel dipekatkan dengan rotari evaporator. Pengujian menggunakan metode Brine Shrimp Lethality Test (BSLT) dan sebagai hewan uji digunakan larva udang Artemia salina Leach. Berat kering sampel $420 \mathrm{~g}$ setelah dimaserasi dengan etanol dan dievaporasi diperoleh berat esktrak kasar $18 \mathrm{~g}$. Analisis probit terhadap data mortalitas larva $A$. salina sebagai indikator potensi antikanker didapatkan nilai LC $_{50}$ $30.01 \mathrm{mg} / \mathrm{l}$.
\end{abstract}

Kata kunci: Uji Potensi , Anti kanker, Teripang laut, Holothuria atra , Artemia salina leach.

\section{PENDAHULUAN}

Teripang merupakan hewan invertebrata yang memiliki tubuh yang lunak, berdaging dan berbentuk silindris memanjang seperti ketimun. Bentuk tersebut menyerupai mentimun sehingga teripang dikenal dengan nama mentimun laut (sea cucumber). Teripang memiliki potensi ekonomi yang cukup tinggi sebagai bahan makanan dengan kandungan gizi dan protein yang juga cukup tinggi. Teripang dapat ditemukan hampir diseluruh perairan pantai, mulai dari daerah pasang surut yang dangkal sampai perairan yang dalam (Martoyo dkk., 2006). Salah satu jenis teripang yang belum banyak dimanfaatkan adalah teripang keling (Holothuria atra). Senyawa bioaktif pada $H$. atra berpotensi untuk digunakan sebagai antimikroba dan antijamur. 
Senyawa bioaktif beberapa diantaranya steroid, terpenoid, flavonoid dan saponin yang merupakan senyawa metabolit sekunder (Abdullah dan Hassan 2012). Senyawa bioaktif yang diduga memiliki aktivitas antikanker terlebih dahulu dilakukan pengujian aktivitas dengan cara uji toksisitas.

Uji toksisitas adalah uji untuk mendeteksi efek toksik suatu zat pada sistem biologi, dan untuk memperoleh data dosis-respon yang khas dari sediaan uji. Data yang diperoleh dapat digunakan untuk memberi informasi mengenai efek sediaan uji tersebut bila terjadi pemaparan pada manusia, sehingga dapat ditentukan dosis penggunaannya demi keamanan manusia. Uji toksisitas ini memiliki tujuan untuk mengetahui tingkat keamanan penggunaan konsumsi suatu senyawa. (Rofiqoh, A dan Difa. 2015)

Tujuan dari pengujian ini adalah untuk mendapatkan data kemampuan aktivitas suatu senyawa bioaktif untuk membunuh sel pada dosis yang kecil sehingga diperoleh data letal konsentrasi atau letal dosis. Kedua ukuran ini sering disebut $\mathrm{LC}_{50}$ atau $\mathrm{LD}_{50}$, yaitu konsentrasi yang dapat membunuh 50\% hewan uji. Umumnya uji toksisitas dapat dilakukan pada hewan kecil dan berumur mudah seperti Artemia salina leach. Pengujian toksisitas dengan menggunakan $A$. salina leach, dikenal dengan metode Brine Shrimp Lethality Test (BSLT) dengan wadah control. Bila hasil pengujian diperoleh dosis yang sangat kecil dengan aktivitas yang tinggi maka dilanjutkan dengan pengujian sitotoksik yang menggunakan sel hidup. Tujuan semua pengujian ini memperoleh senyawa antikanker (Setiadi A. 2012).

Uji toksisitas dalam penelitian biasanya menggunakan $A$. salina Leach sebagai bioindikator dengan metode BLST (Ramdhini, 2010). Uji ini dilakukan dengan cara pemberian konsentrasi tunggal senyawa uji pada hewan percobaan. Ukuran kosentrasi yang dianjurkan minimal empat peringkat konsentrasi, dari kosentrasi terendah yang tidak atau hampir tidak mematikan seluruh hewan uji sampai dengan kosentrasi tertinggi yang dapat mematikan semua atau hampir semua hewan uji. Pengamatan umumnya dilakukan selama 24 jam (Ramadhani,2009). Pengujian toksisitas akut merupakan bagian dari uji toksisitas kuantitatif yang dilakukan dalam jangka waktu yang singkat sebagai akibat dari pemaparan jangka pendek tehadap suatu bahan kimia. Pentingnya biota laut khususnya teripang Holothuria atra sebagai sumber bahan aktif obat-obatan, maka sangatlah perlu dilakukan penelitian tentang aktivitas sitotoksik dari esktrak teripang $H$.atra dengan metode $B S L T$.

\section{METODELOGI PENELITIAN}

Sampel Teripang laut $H$. atra diambil di perairan Desa Kalasey, Kabupaten Minahasa. Preparasi dan uji aktivitas dilakukan di laboratorium Biologi molekuler dan Farmasitika Laut FPIK Unsrat-Manado. Uji toksisitas menggunakan metode BSLT. Analisis data menggunakan analisis probit dengan program minitab untuk menentukan nilai $\mathrm{LC}_{50}$.

Sampel dimaserasi dengan pelarut etanol selama 1 x 24 jam. Larutan ekstrak dipekatkan dengan rotari evapotaror. Pengujian ekstrak dilakukan seri kosentrasi yaitu 5, 25, 50, 75, 100 ppm. Rumus pengenceran seperti diatas mengikuti persamaan $\mathrm{M}_{1} \mathrm{~V}_{1}=\mathrm{M}_{2} \mathrm{~V}_{2}$ (Wahit 1992). Setiap perlakuan di uji diberikan 10 ekor larva udang $A$. Salina.Leach. Pengamatan dilakukan secara bertingkat 4 kali selang 6 jam setelah perlakukan ekstrak. Dalam pengamatan dihitung jumlah larva yang mati. Data pengamatan ditabulasi dalam bentuk tabel dan dialkukan analisis probit dengan program minitab.

\section{HASIL DAN PEMBAHASAN}

$500 \mathrm{~g}$ berat basa teripang $H$. arta diperoleh berat kering $420 \mathrm{~g}$ setelah dimaserasi dan dipekatkan dengan rotarievaporator diperoleh berat ekstrak kasar $18 \mathrm{~g}$. Hasil pengamatan mortalitas hewan ujian berkisar $40-70 \%$. Data tersebut dibuatkan dalam suatu grafik seperti terlihat pada Gambar 1 berikut ini. 


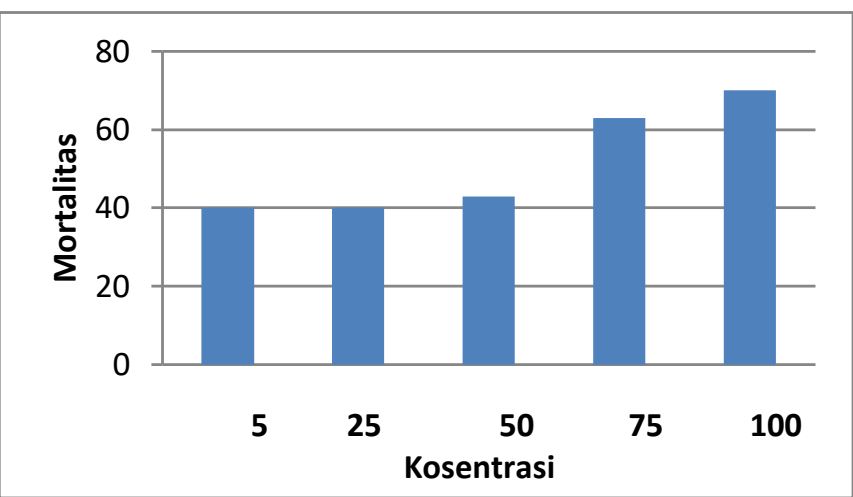

Gambar 1. Grafik perlakukan ekstrak teripang $H$. arta terhadap mortalitas larva A. salina Leach.

Berdasarkan Gambar 1 diatas menunjukkan jumlah mortalitas $A$. Salina sebagai hewan uji dipengaruhi oleh konsentrasi ekstrak $H$. arta dimana makin tinggi kosentrasi uji jumlah mortalitas larva udang $A$. Salina meningkat. Sebagaimana juga ditunjukan pada grafik hasil analisis probit Gambar 2 berikut ini.

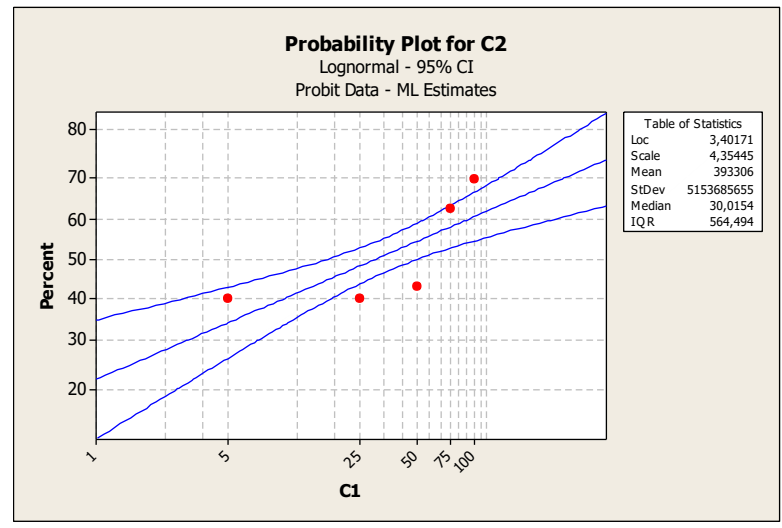

Gambar 2. Grafik analisis probit terhadap mortalitas larva udang A. Salina Leach dari perlakuan ekstrak teripang $H$. arta Hasil analisis probit data mortalitas diperoleh nilai lethal consentrasi ( $\left.\mathrm{LC}_{50}\right)$ $30,01 \mathrm{mg} / \mathrm{l}$. Berdasarkan kristeria tingkat toksisitas senyawa bahan alam menurut Meyer dkk (1982) yang dikutip oleh Ulfa (2014) adalah sebagai berikut suatu senyawa sangat toksik bila nilai $\mathrm{LC}_{50}<30$ ppm, toksik bila $\mathrm{LC}_{50} 30-1000$ ppm dan tidak toksik bila nilai $\mathrm{LC}_{50}>1000 \mathrm{ppm}$

Tingkat kematian larva Artemia salina leach tersebut akan memberikan makna terhadap potensi aktivitas sitotoksik. Menurut Nursid M., (2009) makin kecil nilai $\mathrm{LC}_{50}$ senyawa tersebut makin toksik sebaliknya makin besar nilai $\mathrm{LC}_{50}$ senyawa tersebut makin kurang toksisitas. Kriteria National Cancer Insttitut (NCl) suatu ekstrak dikategorikan aktif apabila nilai toksisitasnya $\left(\mathrm{IC}_{50}\right)<20 \mu \mathrm{g} / \mathrm{ml}$ (Zhmitz dkk., 2001 dalam Kawung 2017).

Hasil analisis probit terhadap toksisitas senyawa bioaktif dari teripanglaut $H$. arta diperoleh nilai $\mathrm{LC}_{50}$ yaitu $30.01 \mathrm{mg} / \mathrm{l}$. Berdasarkan nilai ini dapat dikatakan bahwa teripanglaut $H$. arta mengandung senyawa bioaktif yang bersifat toksit dan dapat dikembangkan sebagai bahan baku obat antikanker.

Umumnya nilai uji toksisitas dapat dinyatakan dalam bentuk $\mathrm{LC}_{50}$ (Lethal Consentration). Nilai LC $_{50}$ artinya konsentrasi sudah dapat membunuh $50 \%$ hewan uji dari semua populasi hewan uji yang digunakan. Berdasarkan nilai uji toksisitas maka akan diketahui apakah senyawa tersebut memiliki efek farmakologis, seperti antitumor atau kanker. Bila nilai konsentrasi $\mathrm{LC}_{50}$ kecil, atau konsentrasi minimum sudah dapat membunuh $50 \%$ hewan uji maka senyawa bioaktif tersebut memiliki khasiat farmakologis untuk dikembangkan sebagai bahan baku antikanker.

\section{KESIMPULAN}

1. Ekstrak kasar teripang laut $H$. arta mengandung senyawa bioaktif yang bersifat toksik terhadap hewan uji $A$. salina L.

2. Nilai $\mathrm{LC}_{50}$ senyawa bioaktif yang terkandung dalam ekstrak kasar teripang laut $H$. arta adalah 30.01 $\mathrm{mg} / \mathrm{l}$.

\section{UCAPAN TERIMA KASIH}

1. Jurnal ini merupakan salah satu syarat untuk melaksanakan ujian skripsi, karena itu saya mengucapkan terimakasih kepada

2. Prof. Ir. Farnis B. Boneka, M.Sc sebagai Dekan FPIK Unsrat

3. Wakil-Wakil Dekan FPIK Unsrat.

4. Dr. Ir. Medy Ompi, M.Sc sebagai Koordinator Program Studi IImu Kelautan FPIK Unsrat 
5. Dr. Veibe Warouw, M. Si sebagai Kepala Laboratorium Biologi Molekuler dan Farmasetika Laut FPIK Unsrat yang memberikan kesempatan untuk menggunakan Laboratorium

\section{DAFTAR PUSTAKA}

Abdullah, H. dan H. Ibrahim. 2012. Antibacterial Carotenoids of Three Holothuria Species in Hurghada, Egypt. Egyptian Journal of Aquatic Research, 38:185-194.

Kawung N.J. 2017. Studi Senyawa Antikanker Dari Karang Lunak Sinularia Sp. Di Perairan Malalayang Dan Pulau Bunaken Sulawesi Utara. Disertasi. Fakultas Perikanan dan IImu Kelautan. Unsrat-Manado.

Martoyo, J., Nugroho, A., dan Tjahjo, W. 2006. Budi Daya Teripang. Edisi Revisi. Jakarta: Penebar Swadaya. Hal. 14.

Nursid, M., D. Fajarningsih dan Th. Wikanta. 2009. Isolation of Cytotoxic Compound from Nephthea sp.. Soft Coral. Jurnal of Biotechnology Research in Tropical Rdegion, Vol. 2, No. 1, Apr. 2009

Mayer BNNR, Ferrigni M.L.1982. brine Shrimp, a convenient general bioassay for active plant constituents, $\mathrm{J}$ of Plant Medical Research (Sp.ecial Edition) ISSN: 1979-9756. Research Center for Marine and Fisheries Product Processing and Biotechnology, Agency of Marine and Fisheries Research, Jalan KS. Tubun Petamburan VI Jakarta.

Ramadhani, AN. 2009, 'Uji toksisitas Akut Ekstrak Etanol Daun Sukun (Artocarpus altilis) terhadap Larva Artemia salina Leach dengan metode Brine Shrimp Lethality Test (BST)', Skripsi, S. Farm, Jurusan Farmasi, Fakultas Kedokteran, Universitas Diponegoro, Semarang, Indonesia.

Ramdhini. 2010. Uji toksisitas terhadap Artemia salina leach dan toksisitas akut komponen bioaktif Pandanus conoideus var.conoideus Lam.
Sebagai kandidat antikanker. Jurnal. Surakarta.

Rofiqoh, Ariek Difa. 2015. Toxicity Subchronic Test of Katuk's Leaves Water Extract (Sauropus androgynous) On the Serum Bilirubin Levels and Hepatic Histology of Female Rat (Rattus norvegicus).

Setiadi A. 2012. Analisis Toksisitas dengan Metode Probit. (http://www.2016). Diakses 18 Agus 2016

Ulfa A. 2012. Uji Toksisitas dan Identifikasi golongan senyawa aktif ekstrak dahan sirsak Amonnna muriccata Linn terhadap larva udang Artemia salina Leach. Skripsi Jurusan Kimia Fakultas sains dan teknologi Universitas Islam Malang 